\title{
НЕЙРОСЕНСОРНАЯ ТУГОУХОСТЬ ПРИ ЛЕГКОЙ ЧЕРЕПНО-МОЗГОВОЙ ТРАВМЕ
}

\author{
Гусейнов Н.М.*, Асади Я.М., Эфендиев А.З., Гашимли Р.М., Фарзулласой С.Г. \\ Азербайджанский Государственный Институт Усовершенствования врачей им. А.Алиева, \\ кафедра Оториноларингологии, Баку, Азербайджан
}

\begin{abstract}
Изучены клинические особенности и патогенез легкой черепно-мозговой травмы (ЛЧМТ) у 106 людей в возрасте от 19 до 54 лет. 66,03\% пострадавших составили мужчины. Наряду с отоларингологическим и неврологическим, проводили иммунологические (циркулирующие иммунные комплексы ЦИК, иммуноглобулины А, M, G) и биохимические (уровень тиобарбитуровой кислоты ТБК-активных продуктов) исследования в динамике в 1-е и на 10-е сутки после травмы. Установлено достоверное повышение содержания ЦИК и ТБК-активных продуктов в 1-е сутки и несколько менее выраженное после клинического выздоровления (к 10-м суткам). Авторы приходят к выводу об участии в патологическом процессе иммунных и биохимических расстройств, приводящих к нарушениям метаболизма и микроциркуляции, что в свою очередь приводит к снижению слуха. Поэтому таким пострадавшим требуется более длительная патогенетическая терапия во избежание развития неврологических и слуховых осложнений в отдаленном периоде после ЛЧМТ у взрослых.
\end{abstract}

Ключевые слова: легкая черепно-мозговая травма (ЛЧМТ), снижение слуха, микроциркуляция.

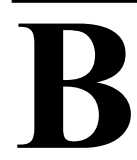

последнее время отмечается значительный рост травматизма [2,4]. На долю черепно-мозговой травмы (ЧМТ) приходится от 20 до 54\% общего числа травматологических больных [3,5]. Чаще всего встречается легкая ЧМТ [1,7]. Ввиду анатомо-физиологических и функциональных особенностей, острый период сотрясения головного мозга, как правило, протекает сравнительно легко. Однако в отдаленном периоде, а иногда и спустя много лет появляется патология слухового аппарата и грубые неврологические дефекты, что значительно затрудняет социальную адаптацию людей и может привести даже к инвалидизации [10].

Важность исследования проблемы нарушения слуха при легкой черепно-мозговой травме обусловлена тем, что она занимает первое место среди механических повреждений и, согласно статистическим данным ВОЗ, увеличивается в среднем на 2\% в год. При этом тенденции к снижению инвалидизации больных не отмечается [11].

Среди всех травматических повреждений черепа 75-80\% составляют легкие черепномозговые травмы (ЛЧМТ), при которых нарушения слуховой функции проявляются в скрытой форме [6,9]. Нарушения слуховой функции нередко выявляются лишь в отдаленном периоде ЛЧМТ, когда купированы клинические симптомы сотрясения или уши- ба головного мозга, а проводимая консервативная терапия не восстанавливает слух. Кроме того, до настоящего времени остаются недостаточно изученными изменения, происходящие в звуковом анализаторе при закрытой черепно-мозговой травме легкой степени $[2,8]$.

Целью исследования явилось изучение особенностей клинического течения и вопросов патогенеза нейросенсорной тугоухости в острый период изолированной легкой черепномозговой травмы с сотрясением головного мозга у взрослых; оценка состояния микроциркуляции, церебрального перфузионного и внутричерепного давления у больных НСТ с изолированной легкой черепно-мозговой травмой, и определение возможных взаимоотношений между ними.

Материалы и методы. Проведено 148 исследований у 106 людей от 19 до 54 лет (сред-

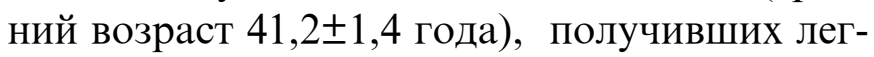
кую черепно-мозговую травму. Мужчин было 70 (66,03\%), женщин 36. Большинство пострадавших были в возрасте 37-42 лет. Всем больным проводилось общеклиническое, оториноларингологическое и неврологическое обследование. У 30 больных исследовали биохимические и иммунологические показатели: продукты перекисного окисления липидов (ПОЛ), в частности концентрацию тиобарбитуровой кислоты (ТБК-активных про-

*e-mail: otorinolorinqologiya_adhti@mail.ru 
дуктов) по методике M.Uchiyama и M.Mihara [10], уровень иммуноглобулинов классов А, M и $\mathrm{G}$ по Манчини, циркулирующие иммунные комплексы (ЦИК) по реакции с полиэтиленгликолем-6000 [9]. Полученные данные сравнивали с показателями контрольной группы (12 здоровых людей). Эти исследования проводили в динамике: в 1-е и 10-е сутки после травмы. Кроме этого, проводили обзорную краниографию, эхоэнцефалоскопию, люмбальную пункцию (по показаниям). Результаты обрабатывались с помощью методов параметрической и непараметрической статистики.

Большинство пострадавших отмечали после травмы головную боль $(92 \%)$, головокружение (77\%), снижение слуха (47\%), общую слабость (96\%). У 31 (37\%) человека сразу же после травмы наблюдалась рвота, иногда многократная, или тошнота. Потеря сознания продолжительностью от нескольких секунд до нескольких минут фиксировалась в основном у больных с травмой затылочной области (23\%). У пострадавших первых лет жизни выраженного нарушения сознания и слуха не отмечалось. После травмы у них выявлялись нарушение сна, сонливость, плаксивость. Редко обнаруживалась ретроградная амнезия. Следует отметить, что классическая триада общемозговых расстройств потеря сознания, рвота и ретроградная амнезия в полном объеме встречалась нечасто (у 6,57\% больных).

При оториноларингологическом обследовании выявлялось снижение слуха, из них по нейросенсорному типу у 47 (33\%) человек, по

кондуктивному типу - у 3 (2\%), по смешанному типу - у 11 (7\%). Из них одностороннее снижение слуха у 45 (42\%), двустороннее у 27 $(23 \%)$ больных. Перфорации барабанной перепонки не было выявлено.

В неврологическом статусе выявлялись мелкоразмашистый горизонтальный нистагм $(57,14 \%)$, сглаженность носогубной складки $(50,55 \%)$, девиация языка $(49,45 \%)$, оживление сухожильных и периостальных рефлексов $(39,56 \%)$. Отмечались вегетативные расстройства в виде колебаний артериального давления, тахикардии, общего или локального гипергидроза. На обзорных краниограммах повреждений костей черепа не было выявлено. При эхоэнцефалоскопии смещения М-эхо не зарегистрировано. При люмбальной пункции отмечалось повышение ликворного давления. Проведенные дополнительные исследования позволили исключить повреждение костей черепа и внутричерепную гематому.

Клиническое выздоровление исчезновение субъективной и объективной неврологической симптоматики наступало к 7 10-м суткам после травмы.

Иммунологические исследования при сотрясении головного мозга у детей выявили значительные сдвиги (табл.). Концентрация ЦИК в 1-е сутки после травмы достоверно превышала показатели контрольной группы (соответственно 112 $\pm 0,83$ ед/мл и $39 \pm 0,46$ ед/мл; р<0,001). Изучение ЦИК на 10-е сутки после ЧМТ также обнаружило повышенные концентрации ЦИК $(76,07 \pm 7,05$ ед/мл), но значительно ниже по сравнению с исходным уровнем $(\mathrm{p}<0,05)$.

Таблица Динамика иммунологических и биохимических показателей в сыворотке периферической крови при сотрясении головного мозга $(\mathrm{M}+\mathrm{m})$

\begin{tabular}{|c|c|c|c|}
\hline \multirow{2}{*}{ Показатель } & \multirow{2}{*}{$\begin{array}{l}\text { Контрольная } \\
\text { группа }\end{array}$} & \multicolumn{2}{|c|}{ Основная группа (n=30) } \\
\hline & & $\begin{array}{c}\text { 1-е сутки после } \\
\text { травмы }\end{array}$ & $\begin{array}{c}\text { 10-е сутки после } \\
\text { травмы }\end{array}$ \\
\hline ЦИК, ед/мл & $39 \pm 0,46$ & $112 \pm 0,83^{*}$ & $76,07 \pm 7,05^{* *}$ \\
\hline $\begin{array}{c}\text { ТБК-активные продукты, } \\
\text { ммоль/л }\end{array}$ & $3,37 \pm 0,46$ & $7,78 \pm 0,24^{*}$ & $5,77 \pm 0,39 * *$ \\
\hline
\end{tabular}

Примечание. Достоверность различий: *-с контрольной группой $($ р<0,001), **-между показателями в 1-е и 10-е сутки после ЧМТ $(\mathbf{p}<0,05)$. 
Исследование гуморального иммунитета не выявило у больных существенных отклонений от нормы. Уровень IgG в 1-е сутки сос-

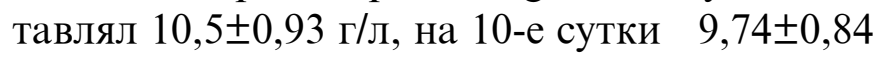
г/л, уровень IgM соответственно 1,08 $\pm 0,09$ и $1,16 \pm 0,09$ г/л, уровень $\operatorname{IgA} 1,48 \pm 0,2$ и

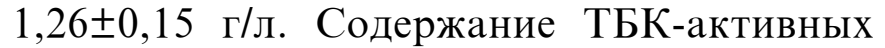
продуктов в 1-е сутки после травмы составило 7,78 $\pm 0,24$ мкмоль/л, на 10-е сутки $5,77 \pm 0,39$ мкмоль/л, что значительно превышало контрольные показатели группы $(3,37 \pm 0,46$ мкмоль/л, $\mathrm{p}<0,001)$. Вместе с тем концентрация ТБК-активных продуктов на 10-е сутки достоверно снизилась $(\mathrm{p}<0,001)$ по сравнению с исходным уровнем в 1-е сутки ЧMT.

Заключение. Таким образом, иммунологические и биохимические исследования выявили достоверное увеличение по сравнению с контрольной группой уровня ЦИК и ТБК-активных продуктов, наиболее выраженное в 1е сутки после ЛЧМТ. Однако к моменту клинического выздоровления, т.е. исчезновения субъективной и объективной неврологической симптоматики, концентрация ЦИК и ТБК-активных продуктов хотя и снижается, но не достигает нормы.

Увеличение концентрации ЦИК при сотрясении головного мозга у взрослых может свидетельствовать о вовлечении иммунопато-

\section{ЛИТЕРАТУРА}

1. Богомильский М. Р., Чистякова В. Р. Детская оториноларингология. М.: ГЭОТАР-МЕД, 2002. 432 с.

2. Бойко AВ, Костенко ЕВ, Батышева ТТ, Зайцев КА. Черепно-мозговая травма. Consillium Medicum. 2007;9(8):5 $10 \mathrm{c.}$

3. Дроздова ЕА, Захаров ВВ. Сравнительная оценка когнитивных нарушений в остром периоде черепномозговой травмы легкой и средней степени тяжести. Неврологический журнал. 2012;17(6):12-8.

4. Захаров ВВ. Нарушение когнитивных функций как медико-социальная проблема. Доктор Ру. 2006;5(30):19-24.

5. Крылов В.В. Лекции по черепно-мозговой травме: Учебное пособие. Москва: ОАО "Издательство "Медицина"; 2010. 320 с.

6. Литвинов ТР. Сравнительная характеристика неврологических и психологических показателей при черепно-мозговой травме. Автореф. дис. канд. мед. наук. логических механизмов, роль которых к моменту клинического выздоровления уменьшается, но полностью не нивелируется.

Процессы ПОЛ при ЛЧМТ активизируются, вызывая повреждение структуры мембран, микроциркуляции и метаболизма. Концентрация токсических продуктов ПОЛ служит показателем степени деструкции мембран. Повышение уровня ТБК-активных продуктов ПОЛ при ЛЧМТ у исследуемых может указывать на метаболические и микроциркуляторные расстройства в ЦНС.

Полученные в настоящем исследовании данные свидетельствуют о том, что после клинического выздоровления у взрослых с легкой ЧМТ в мозговой ткани остаются нарушения на биохимическом и иммунологическом уровнях. Это говорит о необходимости более длительной, чем это принято, патогенетической терапии после сотрясения головного мозга. Рекомендуется использовать препараты, улучшающие микроциркуляцию и обменные процессы в нервной ткани, антиоксиданты, назначать инфузионную терапию для выведения ЦИК в остром периоде ЛЧМТ у взрослых. Такой подход позволит избежать неврологических осложнений в отдаленном периоде ЛЧМТ и ускорит социальную адаптацию пострадавших.

Казань; 2009. 138 с.

7. Сагель МВ. Неврологические и компьютерно-томографические прогностические признаки посттравматической церебральной атрофии: Автореф. дис. канд. мед. наук. Саратов; 2007. 27 с.

8. Holder S. Cognitive impairment in traumatic brain injury cases. Head and brain injuries. 2008;2:34-6.

9. Navratil O, Smrka M, Hanak P. The outcome, working ability and psychic changes after traumatic brain injury. Bratisl Lek Listy. 2006;107(4):110 2.

10. Pandit SR, Sullivan JM, Egger V, Borecki AA, Oleskevich S. Functional effects of adult human olfactory stem cells on early-onset sensorineural hearing loss // Stem Cells. 2011. P.670-677.

11. Zakharov VV, Drozdova EA. Cognitive impairments in patients with brain injury. Neurology, Neuropsychiatry, Psychosomatics. 2013;(4):88-93. 


\title{
XÜLASə
}

\section{YÜNGÜL DӘRӘCӘLİ KəLLӘ-BEYIN TRAVMALARI ZAMANI NEYROSENSOR AĞIREȘITMə}

\author{
Hüseynov N.M., Osədi Y.M., Ofəndiyev A.Z., Həşimli R.M., Fərzullasoy S.Q. \\ O. Oliyev adına Azarbaycan Dövlat Həkimlari Təkmilloşdirmə Institutu, \\ Otorinolarinqologiya kafedrası, Bakl, Azorbaycan
}

Yüngül dərəcəli kəllə-beyin travmalarının (YKBT) klinik xüsusiyyətləri və patogenezi öyrənilmişdir. İmmunoloji və biokimyəvi müayinələr nəticəsində məlum olmuşdur ki, KBT-dən sonra 1-ci sutka ərzində sirkulyasiyaedici immun komplekslər və tiobarbitur turşusu aktiv (TBT-aktiv) məhsulların konsentrasiyasının kontrol qrupla müqayisədə statistik dürüst yüksəlməsi qeydə alınır. Böyüklərdə beyin silkələnmələri zamanı sirkulyasiyaedici immun komplekslərin konsentrasiyasının yüksəlməsi immunopatoloji mexanizmlərin prosesə qoşulması ilə əlaqələndirilə bilər. Tədqiqatın nəticələri böyüklərdə YKBT-də klinik sağalmadan sonra beyin toxumasında biokimyəvi və immunoloji səviyyədə pozuntuların qalmasını göstərir. Bu isə beyin silkələnmələri zamanı patogenetik müalicənin müddətinin ümumi qəbul olunmuş zamandan daha uzun müddətli olmasını ifadə edir. Açar sözlər: yüngül kəllə-beyin travması (YKBT), eşitmənin zəifləməsi, mikrosirkulyasiya.

\section{SUMMARY}

\section{NEUROSENSOR DEAFNESS AFTER MILD CRANIO CEREBRAL TRAUMAS}

\author{
Huseynov N.M., Asadi Y.M., Efendiyev A.Z., Hashimli R.M., Farzullasoy S.Q. \\ Azerbaijan State Advanced Training Institute for Doctors named by A.Aliyev, \\ department of ENT, Baku, Azerbaijan
}

The clinical features and pathogenesis are studied after mild cranio-cerebral trauma (MCCT). As a result of immunological and biochemical examinations, during the 1st day after MCCT the concentration of TBAactive products are statistically reliable raised compared to the control group. The increased concentration of circulant immune complexes (CIC) after mild cranio-cerebral trauma in adults can be linked to the involvement of immunopathological processes. The results of study showed that biochemical and immunological disorders remaining after recovery disease's. It is showed that pathogenic treatment of the mild brain contusion to be longer than the generally accepted time period.

Keywords: mild cranio-cerebral trauma (MCCT), hearing loss, microcirculation.

Redaksiyaya daxil olub: 31.08 .2016

Çapa tövsiyə olunub: 16.09.2016

Rəyçi: t.ü.e.d. Pənahian V.M. 